\title{
The Meaning of Traditional Culture in the College Ideological Education and Measures
}

\author{
Li Su Jing Cai \\ Department of Basic Courses, \\ HeBei College Of Science And Technology, \\ Baoding,China
}

\begin{abstract}
The essence of Chinese traditional culture is our precious spiritual wealth. It is also an important ideological and political education resources. The undergraduate courses in the new period must combine with Chinese traditional culture and the cultural background. The colleges and universities carry out the traditional cultural education which can improve college students' ideological and moral quality, improve college students' humanities accomplishment and help college students establish the correct values of life. Based on the ideological work practice experience, this paper proposes the countermeasure from aspect of teachers, courses, activities and campus culture construction.
\end{abstract}

Keywords: Traditional Culture; Courses; Penetration and Fusion

\section{INTRODUCTION}

The excellent Chinese traditional culture is an effective resource of the contemporary ideological and political education of college students. Chinese traditional culture combined with ideological and political education effectively can make college students' ideological and political education work better, and at the same time, strengthen the actual effect of ideological and political education. Refers to the history of Chinese civilization for thousands of years of Chinese traditional culture in the specific natural environment, economic form and political structure means knowledge form states under the action of the formation and spread of national culture is the Chinese nation in the history of various ideological and cultural ideology of the integrated embodiment of its distinct national unity heredity features such as continuity, inclusiveness and diversity.

Culture is the nation's blood and people's spiritual home. In the process of the national political thought education, traditional cultural education has played an important role in cultural traction actively.

\section{The contemporary university students' mental outlook}

"After 90" shows the vigor and vitality, personality and forthright and sincere of the young generation, but there are also many problems. Netease, Tencent, China education network have listed the contemporary university students of nine cases of crimes (life decay, vice gold diggers, plaything weary in well doing, parasitic dependence, rational gnome, political apathy and speculation, the academic spirit loss, low moral quality, physical and mental defects), although not all of the modern college students have them. The scholar who has engaged in education courses in a university for three years observed in process of teaching and communication with the students that many of them have ideal, but have thought of getting rich quickly, impracticality, strong self-awareness, self-assertion, less collective sense of honor, paying attention to individual ability development and neglecting the teamwork ability, having a strong rebellious spirit, ignoring the social moral constraints, emphasizing on the realization of self-worth, ignoring the significance of social value, serious pragmatism tendency, heavy external light connotation and so on. These phenomena indicate that college students are lack of excellent traditional culture education and edification, which causes the lack of humanistic spirit. Investigating the root cause, it is in the process of transformation of Chinese society, not a very good Chinese excellent traditional culture.

\section{Analysis of the value of traditional culture and political teaching}

Chinese traditional culture is able to pass more than five thousand years. The root cause lies in the stage of its development in different historical periods and the value of existence and reason.

Education courses in colleges and universities teaching are at the main position and the main channel of ideological education for college students, which can guide students to learn and inherit Chinese traditional culture, enhance the cultural connotation of education courses, construct the socialist culture with Chinese characteristics in the new 
period and the socialist core value system and have important realistic significance and far-reaching historical significance.

\subsection{To cultivate college students a sound personality}

Contemporary university education is not only used for imparting professional skills and knowledge, but also for the health mold of perfect personality. Chinese President $\mathrm{Hu}$ Jintao pointed out that a far-sighted person always focuses on the youth. A vision of a political party always put the youth as an important force in social advancement to accelerate the development of history. College students are the hope of the future of our motherland and people and their ideological and moral quality is directly related to the realization of the Chinese dream.

The teacher should pay more attention to the develop education of college students. They also should duly introduce the traditional culture spirit essence into education courses teaching, make it connote the modern interpretation and teach it according to their aptitude. The aim is to inspire and guide students to let students experience their dialectical thinking and accept others selfreceiving, in order to form a sound personality.

\subsection{To cultivate higher vocational students' patriotic feeling}

The ultimate goal of the education courses teaching in colleges and universities is to help college students to form good ideological and political governance quality and good moral quality. The purpose of the course is to train them to establish scientific outlook of the world, the life and the values and form a healthy perfect character throughout the world for thousands of year's history. The important reason of the trials and endless miles of the Chinese nation is that we have profound cultural tradition and a common spiritual home for the nation. Traditional culture embodies the wisdom and strength of the whole nation and education teaching with traditional culture has an integral inner link between them. The best content of Chinese traditional culture is a good material for ideological and moral education of college students.

Chinese traditional culture contains lofty patriotism spirit, such as "henceforth in public", "to public out the private, the people allow pregnant", Gu Yanwu "world rise and fall, fortunes of" patriotism, mind, and so on.

It also includes performance in all forms of Chinese traditional culture, the words, poetry, drama, science and technology and it can stimulate the student to look for the motherland and patriotic heart, enhance national pride and self-confidence.

\subsection{To enhance the pertinence of education courses teaching}

Our country has a long history and profound Chinese culture, nourishes the cohesion of the Chinese nation and inspires the creativity of the Chinese nation to study. Master Nan once said that the inheritance of culture of a country and a nation is fundamental to a country and nation. If culture dies off, it will become a perdition. Hector who never turned into the hall of the United Nations written that do as you would be done by the Chinese motto. This suggests that the Chinese culture still has a profound influence and important position in the cultural globalization and cultural diversity today. Our extensive and profound traditional culture almost involves every field of moral and social level, for every social problem almost can find cited in the traditional culture.

Contemporary college students are increasingly diversified in the era of information network. The survey shows that college students have different degrees of fuzzy ideal and faith, the poor psychological quality, lack of the humanities, and many other problems. In order to solve this problem well, the Chinese nation has a long history of traditional culture, which can provide rich nutrition for the contemporary college students' humanities cultivated manners. The Chinese excellent traditional culture acts as a breakthrough point. The ideological and political education of college students could be more close to the contemporary college students' emotional thought and reality and also easy to be recognized and accepted. The college students in baptism and influence of Chinese excellent traditional culture, they are more acceptable for the good thought moral education, quality education and the ideal personality sentiment education, thus it is more conducive to the healthy growth of college students and all-round development.

\section{Under the new situation in higher vocational students' ideological education in strengthening the way of the traditional culture education}

In today's world of cultural integration, the cultural soft power became more and more important in the competition in overall national power. The great rejuvenation of the Chinese nation is dependent on carrying forward the Chinese traditional culture. We should fully understand Chinese traditional culture. The traditional culture takes the attitude of the materialist dialectics. It is in harmony with the development of Chinese modern society, keeps the national character and spirit of the open inclusive and forms the core competitiveness of the cultural advantage.

\subsection{Innovation education teaching methods}

The development of anything is not invariable and the reform innovation is the soul of development and progress 
of the Chinese nation and the inexhaustible driving force. The excellent traditional culture education for college students should also be due to the circumstances with the first stage. Yan Peng tried to talk about traditional culture and education courses in colleges and universities. As a result of penetration and integration of the arrival of the digital age, the influence of the Internet is very broad. The internet timely propaganda and is not subject to space constraints. When the Internet special features and advantages combines with the traditional culture, it will have a good education effect in the concrete teaching activity. The educators should implement two-way interactive education method instead of traditional Guan Shu Xing. They can classify the unit to carry out the excellent speech competition for ancient Chinese poems, calligraphy, other activities to make others laugh and learn. Universities can also adjust measures to adapt for local conditions and use the traditional cultural resources. The college city has to enrich the content of the traditional culture and patriotism education for college students and social practice of college students education of Chinese traditional culture can be fully implemented by elective courses.

\subsection{Create a good atmosphere to improve traditional cultural universality}

Nowadays, the way of social information dissemination appears a huge change, the traditional education mode has already cannot adapt to today's social development and changes. The development of holiday economy makes college students can use holiday to see more places of interest of the motherland, and experience the native culture and the charm of peace and wisdom. This can enhance the sense of national pride and love of the motherland great rivers, and receive the twice education effect with half the effort. In the process of the traditional culture education of college students. Teachers should actively guide and cultivate college students' enthusiasm to learn the Chinese nation traditional culture and heritage of responsibility, make them be aware that they are not only the learners, also be the beneficiaries of the Chinese nation traditional culture. More importantly than all of that, everyone also should be the guardians of the Chinese nation traditional culture and heritage. Through the learning process of college students from understanding to practice, people close to the faith the internal program cycle by internalization externalization, in order to know and meet the unification and guide them to carry forward the traditional culture.

Creating a good campus culture atmosphere and improving the universality of traditional culture education are very important. First of all, education courses must strengthen the practice teaching link and let students to feel the charm of traditional culture in the practical experience. At the same time, in the information age we also want to make better use of current network education resources which is useful for the publicity and education of Chinese traditional culture. Then we should strengthen the management and construction of school library and give students a good learning atmosphere. As education workers, of course, we first need to improve their cultural quality and moral accomplishment, understand and care about students in the practical work, timely grasp their ideological trend.

\subsection{Schools and the mass media cooperation to carry forward the excellent traditional culture}

Education courses combined with Chinese traditional culture is of great significance and far-reaching. Colleges can support for the realization of education courses and the breakthrough of traditional culture and guarantee the effective integration, including the traditional culture education content in school daily, ideological education work content and the curriculum construction. Colleges should establish full-time teachers team and give a special fund to support education courses. The penetration and integration of traditional culture needs to take various forms which contains its theoretical and practical forms to get real results. It not only needs the theory of classroom education, but also to keep the combination of education and extracurricular fieldwork and take to go out and come in practice way.

The mass media can play a big role and carry forward the excellent traditional culture. In modern society, mass media with its large amount of information, fast transmission speed, strong coverage and attractiveness make the public opinion environment have a profound influence on people. In the social and national levels, we want to use modern means of media, firmly grasp the initiative of ideological and political education, promote active, healthy and positive spirit culture through extensive contacts, grasp and make use of modern resources, create a good social environment of college students' ideological education work.

\section{Conclusion}

Culture is the nation's blood and the spiritual home of people without culture positive lead. A nation can't stands among the peoples of the world connected with Chinese traditional culture in the past. Enlightening the reality is the important support of building socialism with Chinese characteristics cultural power. Implementing the penetration and integration of education courses teaching and the traditional culture not only can enhance the pertinence and effectiveness of education courses teaching, but also make Chinese traditional culture play a great role. 


\section{References}

[1] Zongyu Li. "The value of traditional culture in ideological and political education and its implementation," Journal of Northeast Normal University,pp. 94-97, 2008 .

[2] Weifeng $\mathrm{Yu}$, "To strengthen and deepen the contemporary college students of Chinese excellent traditional culture education practice and thinking," Journal of Sanmenxia Polytechnic, pp. 57-60,2008.

[3] Shuxia Liu," The Chinese traditional culture and political education in colleges and universities education reality status and trend of convergence," Tangdu Journal,pp. 121-124,2011.

[4] Xianghao Zhang, kaibing Shi," The innovation of the Chinese traditional culture and ideological education," Journal of southeast university: philosophy and social sciences,pp.89-92,2008.

[5] Chengjing Mi," The construct in the traditional culture as the carrier of ideological education mechanism of thinking effectively by Wu Lu Ning," Higher Education Exploration, pp.56-59,2008. 